\title{
Genetic Diversity in Cultivars of Phaseolus vulgaris L.by using Biochemical Markers.
}

\author{
Manisha. R. Kapil*1, Varsha. N. Nathar ${ }^{2}$ \\ Molecular Biology Lab, Department of Botany, SantGadge Baba Amravati University, Amravati.
}

\begin{abstract}
SDS-PAGE was used to evaluate and characterize the patterns of seed storage proteins in eight cultivars of Common bean.Electrophorogram for each variety was scored for presence and absence of protein band, which was transformed into a binary data matrix.Jaccards similarity coefficient, generated to determine the genetic similarity among cultivars, it revealed that most of the cultivars were genetically distant from each other. .Eight cultivars of Phaseolus vulgaris L. were investigated for genetic divergence based on seed protein profile using Sodium Dodecyl Sulphate Polyacrylamide Gel Electrophoresis (SDS-PAGE). Based on seed proteins, eleven maximum band were observed in B4 (Beans French yellow )and three minimum number of protein bands in B1 (BB). The highest similarity index was observed in cultivar B2(Surbhi) 0.909 and lowest in B4(Beans French Yellow) and B6(Laffa) 0.272 in both cultivars. The highest dissimilarity value found in B4 and B6 0.728 in both the cultivars and lowest value in B2 cultivar 0.09 The un-weighted paired group method with arithmetic averages (UPGMA) exhibited two clusters $A$ and B which were grouped into four sub-clusters I,II,III and IV. In broader spectrum, the genotypes from various sourcesdiffered in grouping and it was difficult to establish relationship between origin and cluster pattern. Particular clusters were better for specific traits that are suggested to utilize in crop improvement program. It is concluded that SDS-PAGE analysis of common bean seed storage protein is useful for evaluation of genetic variability and cultivars identification that help in common bean breeding program.
\end{abstract}

Keywords: Genetic Diversity, Phaseolus vulgaris L., PhylogeneticAnalysis, Seed Storage Proteins,

\section{Introduction}

PhaseolusvulgarisL.of family Leguminosae originated in Latin America (Southern Mexico and Central America) is an important legume providing major protein source for humans worldwide. In India it is traditionally grown in Hilly trails of Jammu and Kashmir,HimachalPradesh,Uttar Pradesh etc and some parts of Maharashtra state in kharifseason. Common beans usually refers to food legumes of the genus Phaseolus,familyLeguminosae,sub-family Papilionoideae,TribePhaseolae,sub-tribe Phaseolinae.These species represent a wide range of life histories (Annual to perennial), Growth habits (Bush to climbing) reproductive systems and adaptation (from cool to warm and dry to wet).Phaseolus vulgaris L. is known as French Bean, common bean in English,Rajmah in Hindi and Ghewda in Marathi.Common bean is an important legume containing $21.1 \%$ grain proteins, $69.9 \%$ Carbohydrate, $42.5 \mathrm{mg}$ Phosphorus and $12.4 \mathrm{mg}$ Iron in $100 \mathrm{gm} / \mathrm{wt}$ of edible parts (1).Seeds of common bean have valuable nutritional properties due to the fact that they are an important source of fibre,Minerals and vitamins, as well as to their low content of fat and sodium.

Beans are cultivated in different environmental conditions and communities, which partially explains the strong differences in Growth habits and seed types (Gepts,1990).

As seed storage proteins are largely independent of environmental fluctuations, their profiling using SDS-PAGE technology is particularly considered as a consistent tool for economic characterization of germplasm (Javidet al.,2004, Iqbalet al.,2005).The importance of common bean characterization is based on the identification and knowledge of the relevant traits for genetic improvement and ex-situ germplasm conservation.SDS PAGE of proteins is the most commonly used methods to discriminate the varieties. The criteria for distinctness among the cultivars were the presence or absence of a particular band or set of bands occurring at a position on electrophoretic gel and band intensity.SDS PAGE is used for the varietal identification.

The use of genetic markers and protein profiling is also successfully used to resolve the taxonomic and evolutionary problems of several crop plants (Ladizinsky,1979;Murphyet al.,1990;Gaffooret al.,2002. The seed storage protein analysis helps in identification and characterization of diversity in crop varieties, cultivars and their wild varieties but also elaborate genetic transgression and phylogenetic relationship of the accessions. It is also known that variation in protein bands elaborate the relationship among the collection from various geographical regions (Ghafooret al.,2003).Biochemical markers assess accurate genetic diversity index. Therefore, the present study was intendedto investigate genetic diversity in Phaseolus vulgaris L. cultivars as inferred by variations in their morphology and electrophoretic profiles of seed storage proteins as a necessary step for best conservation of Phaseolus vulgaris L. gene pool in India and for future improvement of crop 
characters. Assess the seed protein polymorphism within and different cultivars of common bean. To investigate the geographical distribution of their electrophoretic protein band type. To study phylogenetic relationship among them.

\section{Materialandmethods}

A. Plant material:Eight cultivars of Phaseolus vulgaris L. namely Brown bean (B1), Surbhi (B2), Contender (B3), Beans French Yellow (B4), Kentucky wonder (B5), Laffa (B6), Early master bean (B7) and Painted lady (B8) were obtained from Department of Agriculture, Govt. ofJammu and Kashmir,India and was maintained in the Botanical garden Department of Botany,SantGadgeBabaAmravati University, Amravati.

B. Isolation and extraction of proteins:Total salt soluble proteins were extracted by adding $100 \mathrm{mg}$ of ground seeds in $1 \mathrm{ml}$ of $50 \mathrm{mM}$ tris-HCI $(\mathrm{pH} 7.2)$ and $0.5 \mathrm{M} \mathrm{NaCl}$ at $4{ }^{\circ} \mathrm{C}$ for 60 minutes. This was then frozen at$20^{\circ} \mathrm{C}$ and thawed 3 times during $24 \mathrm{~h}$ to disrupt the tissue and release the proteins (Miller et al., 1972) and centrifugations were at $10000 \mathrm{~g}$ for $15 \mathrm{~min} .20 \mu \mathrm{l}$ of crude protein extract was directly analyzed by SDS PAGE using $15 \%(\mathrm{w} / \mathrm{v})$ Bio-Rad mini protean slab gel. A gel thickness of $0.75 \mathrm{~mm}$ was used for the study $0.1 \%$ Bromo phenol blue used as tracking dye in 1X Sample Loading Buffer.

C. SDS PAGE analysis:SDS- PAGE of seed proteins was carried out in vertical slab gel discontinuous buffer system following the method ofLamelli (1970) using $15 \%$ acrylamide gel concentration. Total volume of $10 \mu \mathrm{l}$ crude protein extract solution was loaded in each well and electrophoresis was carried out at $100 \mathrm{~V}$ until bromo phenol blue reaches the bottom of the gel.Gel were stained with $0.5 \%$ CBBG- 250 over night and destained until the clear bands were observed.

D. Data analysis: Depending upon the presence or absence of polypeptide bands, similarity index was designed for all potential pairs of protein types. The score was 1 for the presence and 0 for absence of bands and used to build dendrogram by unweighted pair-group method with arithmetic averages. All the analyses were carried out using statistical package NTSYS-pc, version 2.0.The stored data file was used to construct a Dendrogram by the Unweighted Pair Group Method with arithmetic means (UPGMA). The matrix was prepared in Microsoft Excel. Only the clear, unambiguous bands were considered for scoring. Each band was denoted as single locus. The locus size was estimated by comparing with a standard protein molecular weight marker. Jaccard'ssimilarityindex (JSI) was calculated by the formula (Sneath and Sokal, 1973).

$\mathbf{S}=\mathbf{W} /(\mathbf{A}+\mathbf{B}-\mathbf{W})$

Where ' $\mathrm{W}$ ' is the number of bands common

' $A$ ' the number of bands in type $A$

' $\mathrm{B}$ ' the number of bands in type B

The similarity matrix generated was converted to a dissimilarity matrix by using formula: -

Dissimilarity = 1 - similarity

\section{Results And Discussions}

Characterization of common bean proteins, on SDS-PAGE electrophoresis of different varieties was done in order to screen out the Molecular weight and genetic diversity of common bean cultivars. In mature seeds type amount of proteins are more constant than other plant tissues. The bands with greater intensity suggested the extra expressions of the polypeptides and the visually light bands confirmed a reduced amount of polypeptide in the sample extract.

The presence or absence of protein bands has also been applied for detection of polymorphism of common bean cultivars .According to the result of SDS-PAGE on different eight cultivars of common bean .In cultivar B4(Beans French Yellow) there is presence of high intense protein bands and maximum number of protein bands i.e 11.Cultivar B1 (Brown Bean) shows minimum number of protein bands i.e 3.

The Dendrogram based on cultivars were grouped into 2 clusters named A1 and A2, (fig.2).Total eight cultivars were studied, from which five common bean cultivars have been placed in group A1 and 3 cultivars of common bean in group A2. Out of five cultivars of cluster A1, Three cultivars B1(Brown bean), B2(Surbhi) and B8 (Painted lady) are placed in sub-cluster I.Cultivars B1 and B2 are closely related to each other so they are placed together while as B8 is placed seperately.Sub cluster II shows the presence of two cultivars B3 and B5.Cluster A2 comprises of total three cultivars B4(Beans French yellow), B6(Laffa) and B7(Early master beans). Out of the these three cultivars B6 Laffa)and B7 (Early master beans)are placed together in Dendrogram as they closely resemble to each other while as B4 has been placed separately as it shows some distinct characters from rest of the two.

Seed protein electrophoresis banding pattern was divided into three regions A, B and C.A and B consists of four bands each while as $\mathrm{C}$ consist of three proteins bands.

In cultivar B1 there is presence of minimum protein bands observed i.e. three bands and in cultivar B2 it shows presence of four bands.CultivarB5(Kentucky wonder) and B8 shows same number of protein bands i.e. 
six number of bands. Cultivar B3 shows presence of seven protein bands. Cultivar B6 and B7 consisted of same number of protein bands i.e eight bands. Cultivar B4 shows presence of high intense bands and maximum number of protein bands (11).Band number 5 and 7 shows presence of polymorphic bands.

Ghafoor and Ahmad (2005) while studying genetic diversity in Vignamungo also reported that SDSPAGE cannot be used for identification of various genotypes on the basis of intraspecific variation because accessions that differed on the basis of characterization and evaluation of morpho agronomic data exhibited similar banding patterns in their seed proteins. Different kinds of electrophoretic method based on cotyledon storage protein patterns have been used for identification and the characterization of crop and herbage cultivars (Cooke,1984).Our findings indicated that SDS-PAGE of Seed proteins supplied additional banding patterns for the discrimination at cultivar level.

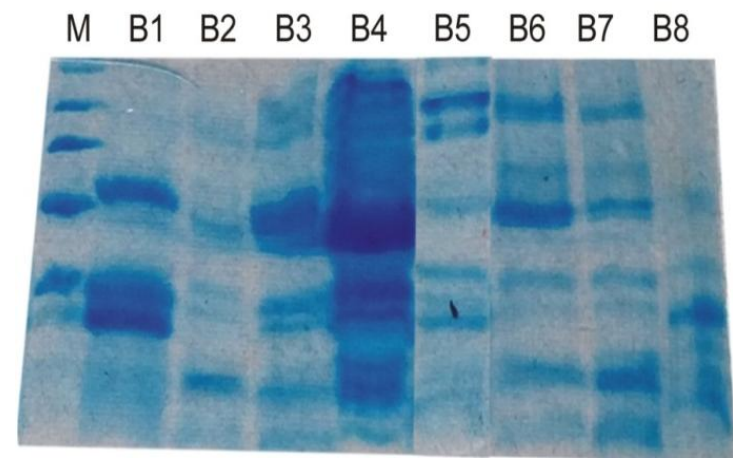

Figure:1 SDS-PAGE patterns of seed storage proteins of Common bean. From left to right the cultivars are of Common bean. From left to right the cultivars are B1- Brown bean,B2-Surbhi,B3-Contender,B4- Beans French yellow, B5-Kentucky wonder,B6-Laffa,B7-Early Master bean and B8-Painted lady.

Table 1: Data matrix illustrating the presence or absence of bands in the seeds protein electrophoresis banding

\begin{tabular}{|c|c|c|c|c|c|c|c|c|c|}
\hline Regions & Band No & B1 & B2 & B3 & B4 & B5 & B6 & B7 & B8 \\
\hline \multirow{4}{*}{ A- 4} & 1 & 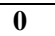 & 0 & $\mathbf{0}$ & 1 & 0 & 0 & 0 & 0 \\
\hline & 2 & 0 & 0 & 1 & 1 & 1 & 1 & 1 & 0 \\
\hline & 3 & 0 & 0 & 1 & 1 & 1 & 1 & 0 & $\mathbf{0}$ \\
\hline & 4 & 0 & 0 & $\mathbf{0}$ & 1 & 0 & 1 & 1 & 1 \\
\hline \multirow{4}{*}{ B-4 } & 5 & 1 & 1 & 1 & 1 & 1 & 1 & 1 & 1 \\
\hline & 6 & 0 & $\mathbf{0}$ & $\mathbf{0}$ & 1 & 1 & 1 & 1 & 1 \\
\hline & 7 & 1 & 1 & 1 & 1 & 1 & 1 & 1 & 1 \\
\hline & 8 & 1 & 1 & 1 & 1 & 1 & o & 1 & 1 \\
\hline \multirow{3}{*}{ C-3 } & 9 & 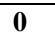 & 0 & $\mathbf{0}$ & 1 & 0 & 1 & 1 & 1 \\
\hline & 10 & $\mathbf{0}$ & 1 & 1 & 1 & 0 & 0 & 0 & 0 \\
\hline & 11 & $\mathbf{0}$ & $\mathbf{0}$ & 1 & 1 & $\mathbf{0}$ & 1 & 1 & $\mathbf{0}$ \\
\hline $\begin{array}{l}\text { Total No. } \\
\text { of Bands }\end{array}$ & & 3 & 4 & 7 & 11 & 6 & 8 & 8 & 6 \\
\hline
\end{tabular}

Table 2: Banding Patterns, Intensity of protein bands and Molecular Weight of SDS Proteins for eight Cultivars of Phaseolus vulgaris $\mathrm{L}$.

\begin{tabular}{|l|l|l|l|l|l|l|l|l|l|l|l|}
\hline Regions & $\begin{array}{l}\text { Band } \\
\text { No }\end{array}$ & $\begin{array}{l}\text { Mol. Wt } \\
\text { KDa }\end{array}$ & Rf & B1 & B2 & B3 & B4 & B5 & B6 & B7 & B8 \\
\hline \multirow{5}{*}{ A-4 } & 1 & 102 & 0.1 & - & - & - & ++ & - & - & - & - \\
\cline { 2 - 13 } & 2 & 100 & 0.10 & - & - & ++ & ++ & ++ & ++ & ++ & - \\
\cline { 2 - 13 } & 3 & 97 & 0.12 & - & - & ++ & ++ & ++ & ++ & - & - \\
\cline { 2 - 13 } & 4 & 45 & 0.20 & - & - & - & ++ & - & ++ & ++ & ++ \\
\hline \multirow{5}{*}{ B-4 } & 5 & 40 & 0.25 & +++ & +++ & +++ & +++ & +++ & +++ & +++ & +++ \\
\cline { 2 - 13 } & 6 & 39 & 0.34 & - & - & - & ++ & ++ & ++ & ++ & ++ \\
\cline { 2 - 12 } & 7 & 35 & 0.42 & +++ & +++ & +++ & +++ & +++ & +++ & +++ & +++ \\
\cline { 2 - 11 } & 8 & 21 & 0.50 & +++ & +++ & +++ & +++ & +++ & - & +++ & +++ \\
\hline \multirow{3}{*}{ C-3 } & 9 & 19 & 0.52 & - & - & - & +++ & - & +++ & +++ & +++ \\
\cline { 2 - 11 } & 10 & 15 & 0.57 & - & + & + & + & - & - & - & - \\
\cline { 2 - 11 } & 11 & 14 & 0.65 & - & - & + & + & - & + & + & - \\
\hline
\end{tabular}

Where,+ - Low Intensity of Protein bands, ++ - Medium Intensity of Protein bands, +++ - High Intensity of Protein bands 
Genetic Diversity in Cultivars of Phaseolus vulgaris L.by using Biochemical Markers.

Table 3.Genetic similarity and dissimilarity matrix of SDS-PAGE Protein data.

\begin{tabular}{|l|l|l|l|l|l|l|l|l|}
\hline & B1 & B2 & B3 & B4 & B5 & B6 & B7 & B8 \\
\hline B1 & 1 & 0.09 & 0.37 & 0.728 & 0.273 & 0.637 & 0.455 & 0.182 \\
\hline B2 & 0.909 & 1 & 0.273 & 0.637 & 0.364 & 0.728 & 0.546 & 0.273 \\
\hline B3 & 0.636 & 0.727 & 1 & 0.364 & 0.273 & 0.455 & 0.455 & 0.546 \\
\hline B4 & 0.272 & 0.363 & 0.636 & 1 & 0.455 & 0.273 & 0.273 & 0.546 \\
\hline B5 & 0.727 & 0.636 & 0.727 & 0.545 & 1 & 0.364 & 0.364 & 0.273 \\
\hline B6 & 0.363 & 0.272 & 0.545 & 0.727 & 0.636 & 1 & 0.182 & 0.455 \\
\hline B7 & 0.545 & 0.454 & 0.545 & 0.727 & 0.636 & 0.818 & 1 & 0.273 \\
\hline B8 & 0.818 & 0.727 & 0.454 & 0.454 & 0.727 & 0.545 & 0.727 & 1 \\
\hline
\end{tabular}

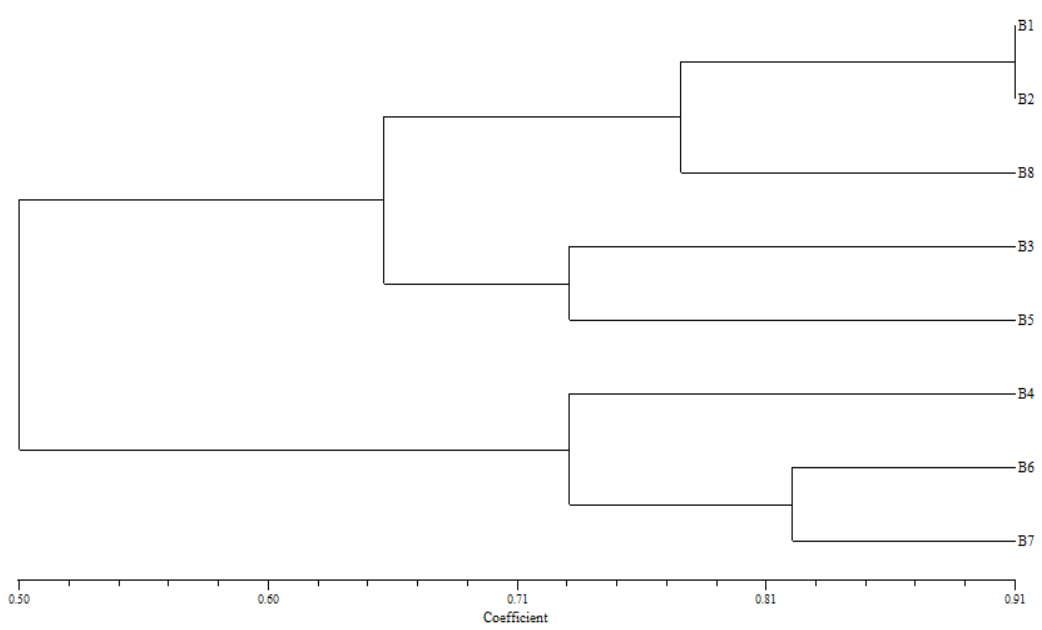

Figure:2 Dendrogram showing the relationship among cultivars of common bean based on SDS-PAGE of totalSeed Storageproteins.

A) Genetic Diversity: Electrophorogram showing proteins banding pattern of different common bean cultivars was presented in fig.1.Based on the results, it is concluded that evaluation of genetic diversity and identification of common bean cultivars by SDS-PAGE is easy, if early approached and useful for molecular weight analysis of common bean seed storage proteins . The study could help common bean breeding programs. The bands obtained with SDS-PAGE were used to compute the similarity co-efficient using the NTYS -clustalsoftware. The common bean cultivars that have been used in the study of seed proteins pattern are shown in Table 1 .Seed protein electrophoresis banding pattern divided into three regions ( $\mathrm{A}, \mathrm{B}$ and $\mathrm{C}$ ) where $\mathrm{A}$ consist of four bands , $\mathrm{B}$ consist of four bands and $\mathrm{C}$ consist of three proteins bands. The Rf value found in the entire profile and presented in Table 2.The presence and absence of a band and the intensity of band were used for varietal characterization. Seed protein analysis of the common bean cultivars studies revealed the presence of eleven bands .Table 2. shows a summary description of band pattern. Relative mobility of bands ranged from 0.1 to 0.65 . Band number of five and seven shows common polymorphic bands. The band with low and medium intensity of Rf value 0.1 to 0.20 was categorized as region A (102-45 KDa) it consist of four bands. Region B ( 40 to $21 \mathrm{KDa}$ ) was characterized with four bands at high very high intensity whose $\mathrm{Rf}$ value lies between 0.25 to 0.50 .In region C (19-14 KDa) three bands with low intensity was appeared with the Rf value of 0.52 to 0.65 .In cultivar B1 there is presence of minimum protein bands observed three bands at molecular distance.Cultivar B5 and B 8 shows same number of protein bands i.e six number of bands with molecular weight of B5 is 100,97,40,39,35 and 21 $\mathrm{KDa}$ and Molecular weight of B8 is 45,40,39,35,21 and 19 KDa.Cultivar B3 shows presence of seven protein bands at Molecular weight distance of 100,97,40,35 and 21 KDa.Cultivar B6 and B7 consisted of same number of protein bands i.e eight protein bands apparently at molecular weight of B6 is 100,97,45,40,39,35,19 and $14 \mathrm{KDa}$ and B7 molecular weight 100,45,40,39,35,21,19 and 14 KDa.Cultivar B4 shows presence of high intense protein bands and maximum eleven number of protein bands occur in germinated common bean extract at molecular weight distance of $102,100,97,45,40,39,35,21,19,15$ and 14.Cultivar B1 shows presence of low and medium intensity of protein bands and minimum number of protein bands three apparently found at molecular weight 40,35 and 21.Band number five and seven shows common polymorphic bands.

B) Cluster Analysis: The diagram from fig. 2 revealed two main group A1 and A2 ,the group A1 has two subcluster I and II.Sub-cluster I has Ia of which shows presence B1 and B2. Sub-cluster Ib consist of single cultivar B8 i.ePL. Sub-cluster II consist of two cultivar B3 and B5 .The group A2 has two sub-clusters III 
and IV .Sub-cluster III consist of single cultivar B4 (BFY) and sub-cluster IV consist of two cultivars B6 and B7.The data (0-1)was used to calculate Jaccard similarity index and dissimilarity index. It showed that there was great similarity between Ia (B1 and B2), Ic (B3 and B5) and Ie (B6 and B7) with similarity index $0.90,0.63,0.81,0.72$ respectively. Sub-cluster Ib shows single cultivars (B8) which show genetic index value 0.818 and dissimilarity index value 0.273 . sub-cluster III also shows one cultivar (B4) genetic value 0.727 and dissimilarity value 0.364.The highest similarity index was observed in cultivar B2 i.e 0.909 and lowest index value in B4 and B6 shows same number 0.272. The highest dissimilarity value B4 and B6 shows same value 0.728 and lowest value in B2 cultivar i.e 0.09. The cultivar B4 and B6 shows same genetic index value i.e 0.27 and lowest dissimilariy value is 0.09 in B2 cutivar.Hence,overall it is observed that all the eight cultivars of Phaseolus vulgaris L. showed some affinities and variations.

\section{Conclusion}

It is concluded that seed storage protein profiles could be useful protein markers in identification of cultivar, Registration of new varieties, Pedigree analysis (breeding program) and in the studies of genetic diversity and classification of adapted cultivars, thereby improving the efficiency of common bean breeding programs in cultivar development. The seed storage protein analysis helps in characterization of diversity in pulses cultivars and their wild varieties and also provides information on phylogenetic relationship of the accessions. The eight bean cultivar formed two distinct groups according to their geographical origin. Variation in protein bands, banding pattern provide information on the relationship among the used seeds collected from various geographical regions. Protein bands used as markers for cultivar characterization. The proteins obtained in the SDS-PAGE electrophoresis were in the range of 102 to $14 \mathrm{kDa}$. A number of protein bands were displayed on the gel, their occurred a diverse pattern about the expression of the polypeptides at different molecular level. Some of the expressed bands shown greater intensities indicated more concentration of the particular proteins.

\section{References}

[1]. Ali M.,Kushwaha,1987. Cultivation of rabirajmash in plains. Indian farming 31(2): 2023.

[2]. Gepts, P. and Debouck,D. 1991. Origin,domestication, and evolution of the common bean (Phaseolus vulgaris L.). In:Schoonhoven A. van and Voysest, O. (Eds.).Common beans: Research for crop

[3]. Javid, A.,Ghafoor,A and R. Anwar. 2004. Seed storage protein electrophoresis in groundnut for evaluating genetic diversity. Pak. J. Bot., 36: 87-96.

[4]. Iqbal, S.H., A. Ghafoor and Ayub.N. 2005. Relationship between SDS-PAGE markers and Ascochyta blight in chickpea. Pak. J. Bot., 37: 87-96.

[5]. Ladizinsky, G. 1979. Species relationships in the genus Lens as indicated by seed protein electrophoresis. Bot. Gaz., 140: 449-451.

[6]. Murphy, R.W., J.W. Sites, D.G. Buth and C.H. Haufler. 1990. Protein I: IsozymeElectrophoresis.In: Molecular Systematics. (Eds.): D.H. Hillis and C. Moritz, pp. 45-126. SinauerAssoc.,Sunderland, MA.

[7]. Ghafoor, A., Z. Ahmad, A.S. Qureshi and M. Bashir. 2002. Genetic relationship in Vignamungo(L.) Hepper and V. radiata (L.) R. Wilczek based on morphological traits and SDS-PAGE. Euphytica, 123: 367-378

[8]. Ghafoor, A., Z. Ahmad, N.I. Hashmi and M. Bashir, 2003. Genetic diversity based on agronomic

[9]. traits and SDS-PAGE markers in relation to geographic pattern of blackgram (Vignamungo(L.) Hepper. Journal of Genetics and Breeding, 57: 5-14.

[10]. Miller, M.K., Schonhorst, M.H., and Mc Daniel, R.G. 1972. Identification of Hybrids from Alfalfa Crosses by Electrophoresis of Single Seed Proteins. Crop Sci., 12: 535-537.

[11]. Laemmli,U.K.1970. Cleavage of structural proteins during the assembly of the head of bacteriophage t . Nature, 227: 680-685.

[12]. Sneath,A. and Sokal,R. 1973. Numerical taxonomy: the principles and practice of numerical classification. W.f. freeman \& co., san francisco, $573 \mathrm{p}$.

[13]. Ghafoor,A. And Ahmad.Z.2005. Diversity of agronomic traits and total seed protein in black gram vignamungo (1.) Hepper. Actabiologiacracoviensia series botanica, 47: 69-75.

[14]. improvement. CAB, Wallingford, UK andCIAT, Cali, Colombia. pp. 7-53.

[15]. Cooke,R.1984.The characterization and identification of crop cultivars by electrophoresis. Electrophoresis, 5: 59-72. 